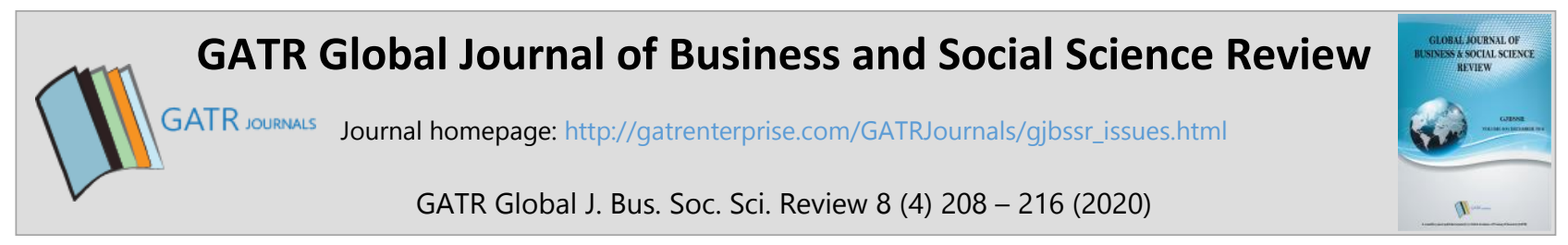

\title{
Transforming into Digital Organization by Orchestrating Culture, Leadership and Competence in Digital Context
}

\author{
Nopriadi Saputra $^{1 *}$, Aldy Maulana Saputra ${ }^{2}$ \\ BINUS Business School, Bina Nusantara University, 11480, Jakarta, Indonesia
}

\begin{abstract}
Objective - For transforming into digital organization; competence of employees, corporate culture and leadership in the digital context become important antecedents. This study attempts to examine the impact of leadership and corporate culture on digital competence

Methodology/Technique -Cross sectional approach is used by involving 280 employees of PT Angkasa Pura I (AP-1) - a stated-owned company who manages the operation of 15 airports in Indonesia as the respondents. The data was structured by PLS SEM and computed by SmartPLS version 3

Finding - Corporate culture and leadership in digital context influenced digital competence significantly and simultaneously. Corporate culture also influences leadership in digital context.

Novelty - For becoming digital organizational, digital competence development can be leveraged by orchestrating digital culture in organizational perspective and digital leadership in group perspective.
\end{abstract}

Type of Paper: Empirical.

JEL Classification: L16, M12, M14

Keywords: Corporate Culture, Leadership, Digital Competence

Reference to this paper should be made as follows: Saputra, N.; Saputra, A.M. (2020). Transforming into Digital Organization by Orchestrating Culture, Leadership and Competence in Digital Context, GATR Global J. Bus. Soc. Sci. Review, 8(4): 208 - 216. https://doi.org/10.35609/gjbssr.2020.8.4(2)

\section{Introduction}

Digital technology is the driver of the future workplace and has a large impact on social and economic aspects, including increased collaboration, competition, and pressure being put on organizations to develop new capabilities (Snow, Fjeldstad, \& Langer, 2017). Digital technology provides opportunities for members of an organization to self-organize and thereby avoid the distortions, delays, and other damaging effects of hierarchically organized systems (Benkler, 2002). The established companies realize that digital technologies can support them conduct businesses with more speed and lower costs and serve the customers with options to co-design and co-produce products and services (Sambamurthy, Bharadwaj, \& Grover, 2003).

\footnotetext{
* Paper Info: Revised: June 10, 2020

Accepted: December 31, 2020

* Corresponding author: Nopriadi Saputra

E-mail: nopriadi.saputra@binus.ac.id

Affiliation: BINUS Business School, Bina Nusantara University, 11480, Jakarta, Indonesia
} 
Many start-up companies use digital technologies to develop new business model and products that disrupt of doing business and take customers away from the established firms which cannot adapt. Digital technologies support decision-making, work activities, connect members of the organization, and help in managing relationships with suppliers, customers, and other stakeholders (Snow, Fjeldstad, \& Langer, 2017).

In digital organization, there are three main assets to be considered: (1) human capital, (2) organizational capital, and (3) computer or technological capital (Ananyin, Zimin, Lugachev, Gimranov, \& Skripkin, 2018) or a powerful combination of people, technology, and organizing ability that is well suited to today's economic and social environment (Snow, Fjeldstad, \& Langer, 2017). Other scholar stated that digital organization has four key factors : (1) digital-first mindset, (2) digitized practices, (3) empowered talent, and (4) data access and collaboration tools (Kontic \& Vidicki, 2018).

This study is based on the business case of PT Angkasa Pura 1 (AP-1) which is a state-owned company that operates fifteen airports in Indonesia. AP-1 has planned to conduct digital transformation and wants to become a digital organization. Because digital organization is populated with teams and individuals who are facile with technology and who can collaborate both inside and outside the organization to make process improvements and develop new solutions (Snow, Fjeldstad, \& Langer, 2017), AP-1 need to develop digital competence of the employees. If digital competence is viewed in organizational behavior, it is influenced by group and organizational factors. So that's why, this study is an attempt to test the impact of digital leadership as a group factor and digital culture as organizational factors on digital competence of airport officers.

\section{Literature Review}

This study uses several theoretical concepts which are relevant to the variables in the research model: digital competence, digital leadership, and digital culture.

\subsection{Digital Competence}

Digital competence needs the critical, confident, and responsible use of, and engagement with, digital technologies at work, for participation in society and for learning (European Commission, 2018, p. 5). Main elements of digital competence were identified in terms of the knowledge, skills and attitudes needed to be digitally which is reflected into of 21 competences in 5 competence areas: (1) information and literacy, (2) communication and collaboration, (3) digital content creation, (4) safety, and (5) problem solving (Bertolome, et al., 2018). In airport context, the competence of airport officers is not only related to the digital skill only but also with the psycho-social aspect for serving people from all over Indonesia and other countries. So that's why on this study, digital competence is a combination of world class criteria for airport officers and digital skill. The world class criteria consist of psycho-social aspect: (1) continuous improvement, (2) proactivity, (3) integrity, (4) innovative, (5) professionalism, (6) collaboration, and (7) service orientation. Meanwhile, digital skill is composed by (1) internet communication skill, (2) content creation skill, and (3) strategic internet skill.

\section{2 Digital Leadership}

Digital leadership is also known as e-leadership or virtual leadership. It is related to a competence in virtual or ICT-mediated social influence that may produce a change in performance, behaviour, thinking, feelings, and attitudes (Farr, 2010). It has become essentially valuable for leaders at every level, both inside and outside of the organization. Digital leadership includes : e-trustworthiness, e-technology skills, e-change management, e-team building, e-social skills, and. e-communication (Van Mart, Roman, Wang, \& Liu, 
2019). For this study, digital leadership is reflected into digital attitude and leadership skills (Rudito \& Sinaga , 2017).

Previous empirical studies have proven that leadership and competence or skill or ability mutually influence each other. In the context of small-medium enterprise, transformational leadership, technical and entrepreneurial competence of owner-managers have a positive, substantial impact on the business success (Ng, Kee, \& Ramayah, 2016). In education institution, leadership style influenced job commitment, and sense of competence (Adeokin \& Kazeem, 2017). In elementary and middle school level, leadership of coordinators was a powerful predictor of students' digital collaboration skills (Blau, Shamir-Inbval, \& Hadad, 2020). Based on these empirical facts, this study arranges the hypothesis:

H1: Digital leadership impacts on digital competence positively and significantly

\subsection{Digital Culture}

If digital competence is viewed in organizational behavior perspective, it is influenced by various antecedents: individual, group, and organizational. Corporate culture as organizational antecedent has an influential impact on digital competence. Corporate culture as value system with a set of standards is unique for each organization and can result in self-understanding and mutual interaction of people in the organization (Hiyks, Vetrakova, Balazova, \& Danihelova, 2015). Digital culture is corporate culture which supports and endorses utilization of digital technology for aiming sustainable business success (Rudito \& Sinaga , 2017). Based on previous research (Rudito \& Sinaga , 2017), this study defines digital culture into digital mindset and digital values.

Previous empirical studies have shown that culture impacts on skill or ability or competence development. Cultural intelligence is important for digital leadership, especially when managing a diverse workforce from various cultural perspectives within one organizational framework. It is an important tool for leadership success in a digital world (Ruth \& Netzer, 2020). In education, organizational culture played a mediation effect on academic leadership skills and student's skill (Radwan, Razak, \& Ghavifekr, 2019). Based on these empirical researches, this study hypotheses that:

H2: Digital culture impacts positively and significantly on digital competence

Previous studies also explained that culture and leadership mutually influence each other. Culture was reported more responsive to influence leadership rather than leadership was to culture. Corporate culture may be predicted by a mixture of transactional and transformational leadership approaches (Sarros, Gray, \& Densten, 2002). Corporate culture plays a moderating role on impact of transformational leadership to cynical about organizational change (Rahman \& Hadi, 2019). Based on these empirical works, this study formulates the hypothesis that:

H3: Digital culture impact positively and significantly on digital leadership

\section{Research Methodology}

\subsection{Material and Method}

This study is based on quantitative research by using online questionnaire and involved the airport officers at PT Angkasa Pura 1 (AP 1) who serve the operationalization of 15 airports in Indonesia. Those airports are Ahmad Yani, Adi Soemarmo, Adi Sutjipto, New Yogyakarta International, Juanda, Ngurah Rai, Lombok, Sepinggan, Syamsudin Noor, Sultan Hasanuddin, Sam Ratulangi, Sentani, El Tari, Frans Kaiseiepo, and Pattimura Airport. This study involved 280 from 489 airport officers of AP1. Most of respondents are male

GATR Global J. Bus. Soc. Sci. Review 8 (4) 208 -216 (2020) 
(63\%), with age below 40 years old (59\%) have bachelor's degree (71\%), and more than 10 years of service in AP $1(55 \%)$.

Table 1. Profile of Respondents

\begin{tabular}{|c|c|c|c|}
\hline \multicolumn{4}{|c|}{ Profile of Respondents } \\
\hline & Male & 176 & $63 \%$ \\
\hline Gender & Female & 104 & $37 \%$ \\
\hline \multirow{4}{*}{ Age } & $20-29$ & 64 & $23 \%$ \\
\hline & $30-39$ & 102 & $36 \%$ \\
\hline & $40-49$ & 52 & $19 \%$ \\
\hline & $50-$ up & 62 & $22 \%$ \\
\hline \multirow{4}{*}{ Education } & Diploma & 31 & $11 \%$ \\
\hline & Bachelor & 198 & $71 \%$ \\
\hline & Master & 49 & $18 \%$ \\
\hline & Doctor & 2 & $1 \%$ \\
\hline \multirow{4}{*}{ Years of service } & up to 2 year & 14 & $5 \%$ \\
\hline & $3-5$ years & 34 & $12 \%$ \\
\hline & 6 - 10 years & 77 & $28 \%$ \\
\hline & More than 10 years & 155 & $55 \%$ \\
\hline \multirow{2}{*}{ Job Function } & Operation & 145 & $52 \%$ \\
\hline & Supporting Administration & 135 & $48 \%$ \\
\hline
\end{tabular}

\subsection{Measurement Model}

Research model consists of structural and measurement model. Structural model defines the interrelationship among variables. Research model is developed by three variables: Digital Competence, Digital Leadership, and Digital Culture. Second order type is used as measurement model which all variables are reflected into its dimensions and all dimensions are measured by its indicators. As independent variable, Digital Competence is reflected into World Class Criteria which is measured by ten indicators and Digital Skill which is measured by four indicators. As intervening variable, Digital Leadership is described into Digital Attitude which is measured by six indicators and Leadership Skill is measured by seven indicators. As independent variable, Digital Culture is defined as Digital Mindset which is measured by eight indicators and Digital Value which is measured by six indicators.

Table 2 dan [I do not know what this means] Table 3 shows result of validity and reliability analysis for indicators, dimensions, and variables. For indicators, Outer Loading score is for validity analysis. An indicator is valid when Outer Loading is more than 0,70. All items of all indicators have Outer Score more than 0,70. It means that all indicators o in the measurement model are valid. For validity of dimension or variables, average variance extracted, or AVE score is used. It is valid when it has AVE score more than 0,5. All dimensions and all variables have AVE score more than 0.50. It means all variables and its dimension are valid for use in measurement mode.

For reliability, Cronbach's Alpha (CA) score in Table 2 and determinant validity in Table 3 can be used. A variable or dimension is reliable when $\mathrm{CA}$ is more than 0,7 . All variables and dimensions have CA score more than 0,7. It means that all variables and its dimensions are reliable. Discriminant reliability supports that reliability result. All bold diagonally scores in Table 3 are higher than 0,7 and bigger than all scores in the same row. It indicates that all dimensions are reliable 
Table 2. Validity and Reliability

\begin{tabular}{|c|c|c|c|c|c|c|c|c|c|}
\hline Dimension & Item & $\begin{array}{c}\text { Outer } \\
\text { Loading }\end{array}$ & $\begin{array}{c}\text { Cronbach's } \\
\text { Alpha }\end{array}$ & AVE & Dimension & Item & $\begin{array}{c}\text { Outer } \\
\text { Loading }\end{array}$ & $\begin{array}{c}\text { Cronbach's } \\
\text { Alpha }\end{array}$ & AVE \\
\hline \multicolumn{3}{|c|}{ DIGITAL COMPETENCE } & 0,933 & 0,541 & \multicolumn{3}{|c|}{ DIGITAL LEADERSHIP } & 0,946 & 0,607 \\
\hline \multirow{9}{*}{$\begin{array}{c}\text { World Class } \\
\text { Criteria }\end{array}$} & WC03 & 0,726 & \multirow{9}{*}{0,928} & \multirow{9}{*}{0,609} & \multirow{7}{*}{$\begin{array}{l}\text { Leadership } \\
\text { Skill }\end{array}$} & TL01 & 0,832 & \multirow{7}{*}{0,918} & \multirow{7}{*}{0,671} \\
\hline & WC04 & 0,717 & & & & TL02 & 0,805 & & \\
\hline & WC07 & 0,724 & & & & TL03 & 0,838 & & \\
\hline & WC08 & 0,807 & & & & TL04 & 0,814 & & \\
\hline & WC09 & 0,807 & & & & VL01 & 0,765 & & \\
\hline & WC10 & 0,806 & & & & VL02 & 0,837 & & \\
\hline & WC11 & 0,804 & & & & VL03 & 0,842 & & \\
\hline & WC13 & 0,750 & & & \multicolumn{3}{|c|}{ DIGITAL CULTURE } & 0,942 & 0,572 \\
\hline & WC14 & 0,805 & & & \multirow{8}{*}{$\begin{array}{l}\text { Digital } \\
\text { Mindset }\end{array}$} & AN01 & 0,799 & \multirow{8}{*}{0,923} & \multirow{8}{*}{0,650} \\
\hline \multirow{4}{*}{ Digital Skill } & CS01 & 0,713 & \multirow{4}{*}{0,795} & \multirow{4}{*}{0,620} & & AN02 & 0,847 & & \\
\hline & SS01 & 0,778 & & & & CR01 & 0,811 & & \\
\hline & $\mathrm{SS} 02$ & 0,861 & & & & CR02 & 0,806 & & \\
\hline & $\mathrm{SS} 03$ & 0,791 & & & & NW01 & 0,831 & & \\
\hline DIGITAI & LEADE & SHIP & 0,946 & 0,607 & & NW02 & 0,802 & & \\
\hline \multirow{7}{*}{$\begin{array}{l}\text { Digital } \\
\text { Attitude }\end{array}$} & & & & & & OP01 & 0,731 & & \\
\hline & DK01 & 0,791 & & & & OP02 & 0,817 & & \\
\hline & DK02 & 0,826 & & & \multirow{6}{*}{$\begin{array}{l}\text { Digital } \\
\text { Value }\end{array}$} & AG01 & 0,714 & \multirow{6}{*}{0,854} & \multirow{6}{*}{0,578} \\
\hline & DK03 & 0,842 & 0,889 & 0,643 & & AG03 & 0,741 & & \\
\hline & DX01 & 0,812 & & & & EX01 & 0,803 & & \\
\hline & DX02 & 0,749 & & & & EX02 & 0,791 & & \\
\hline & DX03 & 0,791 & & & & IN01 & 0,758 & & \\
\hline & & & & & & IN02 & 0,751 & & \\
\hline
\end{tabular}

Table 3. Discriminant Validity

\begin{tabular}{lccccccc}
\hline & & {$[1]$} & {$[2]$} & {$[3]$} & {$[4]$} & {$[5]$} & {$[6]$} \\
\hline \hline$[1]$ & Digital Attitude & 0,802 & & & & & \\
{$[2]$} & Digital Mindset & 0,227 & 0,806 & & & & \\
{$[3]$} & Digital Skill & 0,489 & 0,366 & 0,787 & & & \\
{$[4]$} & Digital Value & 0,235 & 0,743 & 0,354 & 0,760 & & \\
{$[5]$} & Leadership Skill & 0,743 & 0,237 & 0,511 & 0,218 & 0,819 & \\
{$[6]$} & World Class Criteria & 0,545 & 0,413 & 0,722 & 0,426 & 0,566 & 0,780 \\
\hline \hline
\end{tabular}

Table 4 shows the path coefficient of variable to its dimensions. All path coefficients are indicated with pValue less than 0,005 or t-Statistics more than 1,96. It means that all variables are reflected into its dimension significantly. Based on validity, reliability, and path analysis; this study states that all variables are reflected into its dimensions and measured by its indicators are valid, reliable, and significant. 
Table 4. Outer Path Coefficient

\begin{tabular}{cccccc}
\hline Variable & Dimensions & Path Coefficient & t- Statistics & p-Values & Result \\
\hline \hline \multirow{2}{*}{ Digital Competence } & World Class Criteria & 0,978 & 448,093 & 0,000 & Significant \\
& Digital Skill & 0,850 & 52,330 & 0,000 & Significant \\
\hline \multirow{2}{*}{ Digital Leadership } & Digital Attitude & 0,951 & 165,006 & 0,000 & Significant \\
& Leadership Skill & 0,249 & 4,453 & 0,000 & Significant \\
\hline \multirow{2}{*}{ Learning Culture } & Digital Mindset & 0,975 & 305,001 & 0,000 & Significant \\
& Digital Value & 0,942 & 119,486 & 0,000 & Significant \\
\hline \hline
\end{tabular}

\section{Results}

Research model is demonstrated in Figure 1. Table 5 provides the result of hypothesis testing. Path coefficient of all hypothesis have t-Statistics more than 1,96 and p-Values less than 0,05. It means that all hypotheses are accepted. Digital competence is influenced by digital leadership and digital culture significantly. Digital culture also impacts on digital leadership. Digital leadership does not play moderating role on relationship between digital culture to digital competence. Because the direct effect $(0,317)$ is still bigger than the indirect effect $(0,129=0,249 \times 0,520)$.

Table 5. Hypothesis Testing

\begin{tabular}{cccccc}
\hline & Hypothesis & Path Coefficient & t-Statistics & p-Values & Result \\
\hline \hline H1: & Digital Leadership $\rightarrow$ Digital Competence & 0,520 & 12,107 & 0,000 & Accepted \\
H2: & Digital Culture $\rightarrow$ Digital Competence & 0,317 & 6,166 & 0,000 & Accepted \\
H3: & Digital Culture $\rightarrow$ Digital Leadership & 0,249 & 4,453 & 0,000 & Accepted \\
\hline \hline
\end{tabular}




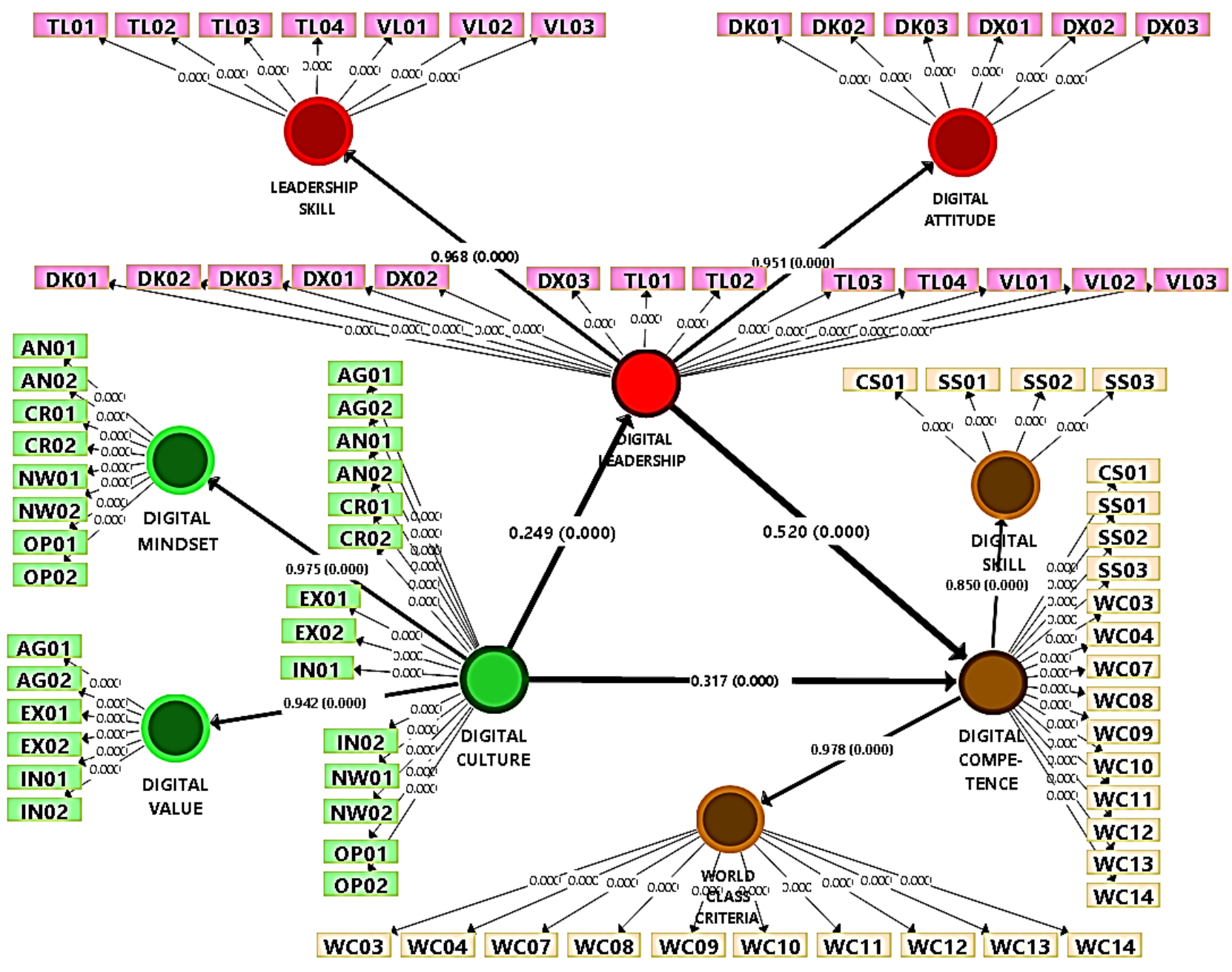

Figure 1. Research Model

\section{Discussion}

On-becoming digital organization, especially with actor-oriented architecture, there are three main elements to be considered (1) actors who have the values and capabilities to self-organize; (2) commons where the actors share and accumulate resources to work and collaborate with other actors; and (3) protocols, processes, and infrastructures that enable multi-actor collaboration (Snow, Fjeldstad, \& Langer, 2017). It requires work skills in area: (1) sense-making, (2) social intelligence, (3) cross cultural competency, (4) computational thinking, (5) media literacy, (6) trans-disciplinary, (7) design mindset, (8)cognitive load management, and (9) virtual collaboration. These skills can be categorized into two groups: psycho-social and technological aspect. In line with this categorization, digital competence in this study is also reflected into two dimensions: world class criteria as psycho-social aspect and digital skill as technological aspect. World class criteria is defined as ability of airport officer to demonstrate work habits which related to (1) continuous improvement, (2) proactivity, (3) integrity, (4) innovation, (5) professional, (6) collaboration, and (7) service oriented. Meanwhile, digital skill as technological aspect describes ability of airport officers in utilizing digital technologies for working and collaborating in service people in airport. Digital skill is composed by digital communication skill, content creation skill, and strategic digital skill.

For accelerating the digital transformation, the organization may leverage and sustain the digital competence of airport officers by improving the digital leadership of airport supervisor and manager. Digital leadership is ability of supervisor or manager in utilizing digital technologies to influence and direct her/his

GATR Global J. Bus. Soc. Sci. Review 8 (4) 208 -216 (2020) 
team to aim collective objectives and ability to improve digital skill of team-members. Digital skill is reflected into digital attitudes and leadership skill. By improving digital attitudes and leadership skill of supervisors and managers, it impacts on improvement in digital competence of airport officers.

Besides digital leadership, digital culture as organizational factor plays an influential role. Digital culture is organizational or corporate culture which support, endorse, and nurture the utilization of digital technologies in organization for working and collaborating. Digital culture is related to digital mindset and digital value. It is relevant to key factors of digital organization. Digital organization needs: (1) digital-first mindset, (2) digitized practices, (3) empowered talent, and (4) data access and collaboration tools (Kontic \& Vidicki, 2018) in whole organization. Digital culture is related to digital-first mindset, digitized practices, and empowered talent. Developing digital culture in organization impacts on improving the digital leadership of supervisor or manager and leveraging the digital competence of airport officers.

\section{Conclusion}

For transforming into digital organization, digital competence of the whole employee in organization is an essential issue. Developing digital competence of individuals and teams as actors in actor-oriented architecture is needed, Digital competence is not only related to digital skill, but also includes the psychosocial aspect such as world class criteria for airport organization. Corporate culture in digital context as organizational factor and digital leadership of supervisor and manager as group factors positively and impact significantly on digital competence development. Digital culture also has significant impact on digital leadership. By orchestrating corporate culture and leadership in digital context, digital competence can be leveraged, and digital organization is possible to be established.

\section{References}

Adeokin, B. S., \& Kazeem, O. O. (2017). The Impact of Leadership Style and Sense of Competence on the Performance of Post-Primary School Teachers in Oyo State, Nigeria. International Journal of Educational and Pedagogical Sciences, 11(12), 2785-2791.

Ananyin, V. I., Zimin, K. V., Lugachev, M. I., Gimranov, R. D., \& Skripkin, K. G. (2018). Digital organization: Transformation into the new reality. Бизнес-информатика, (2 (44) eng).

Benkler, Y. (2002). Coase's Penguin, or, Linux and" The Nature of the Firm". Yale law journal, 369-446. https://doi.org/10.2307/1562247

Bartolomé, J., de Soria, I. M., Jakobsone, M., Fernández, A., Ruseva, G., Koutoudis, P., ... \& Vaquero, M. (2018, March). Developing a digital competence assessment and accreditation platform for digital profiles. In Proceedings of the 12th International Technology, Education and Development Conference (INTED), Valencia, Spain (pp. 5-7). doi: 10.21125/inted.2018

Blau, L., Shamir-Inbval, T., \& Hadad, S. (2020). Digital collaborative learning in elementary and middle school as a fucnction of individualistic and collective culture: The role of ICT coordinator's leadership experience, students' collaboration skills, and sustainability. Journal of Computer Assisted Learning.

Council, E. (2018). Council Recommendation on Key Competences for Lifelong Learning. Brussels.

Farr, S. (2010). Teaching as leadership: The highly effective teacher's guide to closing the achievement gap. John Wiley \& Sons.

Hitka, M., Vetráková, M., Balážová, Ž., \& Danihelová, Z. (2015). Corporate culture as a tool for competitiveness improvement. Procedia Economics and Finance, 34, 27-34. https://doi.org/10.1016/S2212-5671(15)01597-X

Kontić, L., \& Vidicki, Đ. (2018). Strategy for digital organization: Testing a measurement tool for digital transformation. Strategic Management, 23(1), 29-35. DOI: 10.5937/StraMan1801029K

$\mathrm{Ng}$, H. S., Kee, D. M. H., \& Ramayah, T. (2016). The role of transformational leadership, entrepreneurial competence and technical competence on enterprise success of owner-managed SMEs. Journal of General Management, 42(1), 2343. https://doi.org/10.1177/030630701604200103 
Radwan, O., Razak, A. Z. A., \& Ghavifekr, S. (2019). The Mediating Effect of Organisational Culture on Academic Leadership Skills And Students'skill-Based Learning Outcomes In Saudi Higher Education. Mojem: Malaysian Online Journal of Educational Management, 8(1), 39-57.

Rahman, Z., \& Hadi, H. K. (2019). Does Organizational Culture Matters in Organizational Change? Transformational Leadership and Cynicism About Organizational Change. KnE Social Sciences, 353-362. DOI 10.18502/kss.v3i11.4019 Roman, A. V., Van Wart, M., Wang, X., Liu, C., Kim, S., \& McCarthy, A. (2019). Defining e-leadership as competence in ICT-mediated communications: an exploratory assessment. Public Administration Review, 79(6), 853-866. https://doi.org/10.1111/puar.12980

Rudito, P., \& Sinaga, M. F. (2017). Digital Mastery, Building Digital Leadership to Win the Era of Disruption. Gramedia Pustaka Utama.

Rüth, R., \& Netzer, T. (2020). The key elements of cultural intelligence as a driver for digital leadership success. Leadership, Education, Personality: An Interdisciplinary Journal, 1-6. https://doi.org/10.1365/s42681-019-00005-x

Sambamurthy, V., Bharadwaj, A., \& Grover, V. (2003). Shaping agility through digital options: Reconceptualizing the role of information technology in contemporary firms. MIS quarterly, 237-263. https://doi.org/10.2307/30036530

Sarros, J. C., Gray, J., \& Densten, I. L. (2002). Leadership and its impact on organizational culture. International Journal of Business Studies, 10(2).

Snow, C. C., Fjeldstad, Ø. D., \& Langer, A. M. (2017). Designing the digital organization. Journal of Organization Design, 6(1), 7. https://doi.org/10.1186/s41469-017-0017-y

Van Wart, M., Roman, A., Wang, X., \& Liu, C. (2019). Operationalizing the definition of e-leadership: identifying the elements of e-leadership. International Review of Administrative Sciences, 85(1), 80-97. https://doi.org/10.1177/0020852316681446 